Jurnal Bimas Islam Vol 14 No. 2

Website: jurnalbimasislam.kemenag.go.id/index.php/jbi

ISSN 2657-1188 (online) ISSN 1978-9009 (print)

\title{
Respons Komunitas Muslim Indonesia terhadap Wabah COVID-19
}

\section{The Responses of Indonesian Muslim Religious Community to the COVID-19 Pandemic}

\author{
Ahmad Taufik \\ Dosen UIN Sulthan Thaha Saifuddin Jambi \\ e-mail: ahmadtaufik@uinjambi.ac.id
}

Artikel diterima 04 April 2021, diseleksi 18 Juni 2021

dan disetujui 20 Desember 2021

Abstrak: Para pemuka agama di Indonesia dinilai memiliki peran strategis pada masa pandemi COVID-19 karena keputusan dan perilaku mereka menjadi pedoman bagi sebagian besar komunitas Muslim. Oleh karena itu, studi ini bertujuan untuk menganalisis respons organisasi Islam arus utama seperti Nahdlatul Ulama (NU), Muhammadiyah (MU), Majelis Ulama Indonesia (MUI), Jamaah Tabligh (JT) dan Front Pembela Islam (FPI) dan beberapa pemuka agama Islam seperti Ustadz Abdul Somad dan Kyai Najih di Indonesia selama menghadapi COVID-19. Penelitian ini menggunakan metode kajian literatur (studi pustaka), dengan sumber data utama yang diperoleh dari situs-situs media online, website, dan youtube. Data-data tersebut kemudian dianalisis menggunakan analisis wacana kritis yang dirumuskan oleh Norman Fairclough dengan Pendekatan Relasional Dialektikal (Dialectical-Relational Approach/DRA). Penelitian ini menemukan bahwa tanggapan beberapa komunitas Muslim terhadap COVID-19 terbagi ke dalam respons positif dan negatif. Respons negatif tampak dari sejumlah pemuka agama yang masih menganjurkan kegiatan ibadah secara berkerumun, dengan tidak mentaati protokol kesehatan, sebagaimana dianjurkan pemerintah. Bahkan, respons ini didukung oleh teori-teori konspirasi dari Zionis dan dugaan ikut campurnya pihak Barat, dan beberapa alasan ideologis keagamaan. Respons positif justru 
ditunjukkan oleh beberapa ormas Islam arus utama seperti NU, MU, dan MUI, yang merespons COVID-19 secara logis dan realistis. Mereka meminta para simpatisannya untuk mematuhi PSBB, sebagaimana dianjurkan pemerintah dan turun ke lapangan untuk membantu masyarakat terdampak COVID-19.

Kata Kunci : COVID-19, pandemi, pemuka agama, Indonesia, respons negatif dan positif.

Abstract: Some religious leaders in Indonesia are considered to have a strategic role during the COVID-19 pandemic because their decisions and behaviors serve as guidelines for most of the Muslim community. Therefore, this study aims to analyze the responses of mainstream Islamic organizations such as Nahdlatul Ulama (NU), Muhammadiyah (MU), Indonesian Ulema Council (MUI), Tablighi Jamaat (JT) and the Islamic Defenders Front (FPI) and several Islamic religious leaders, such as Ustadz Abdul Somad and Kyai Najih in Indonesia during the COVID-19 pandemic. This study uses a literature review method (literature study), with the main data sources obtained from online media sites, websites, and youtube. These data are analyzed by using critical discourse analysis formulated by Norman Fairclough with the Dialectical-Relational Approach (DRA). This study is finding that the response of some Muslim community to COVID-19 was divided into positive and negative responses. The negative response was seen from a number of religious leaders who still advocated worship activities in crowds, by not obeying health protocols, as recommended by the government. In fact, these responses are supported by Zionist conspiracy theories and alleged Western meddling, and some religious ideological reasons. A positive response was actually shown by several mainstream Islamic organizations such as NU, MU, and MUI, which responded logically and realistically to COVID-19. They asked their sympathizers to comply with the PSBB, as recommended by the government and they help people affected by COVID-19.

Keywords : COVID-19, pandemic, religious leader, Indonesia, negative and positive responses. 


\section{A. Pendahuluan}

Sejumlah media massa memberitakan bahwa komunitas beragama menjadi salah satu kelompok utama penular virus COVID-19. ${ }^{1}$ Di Korea Selatan, 5.000 orang terkonfirmasi positif COVID-19 akibat tertular dari "pasien 31" setelah melakukan peribadatan di Shincheonji Church of Jesus di Daegu. Di California, 71 kasus COVID-19 terkonfirmasi dan setelah ditelusuri, ternyata berasal dari sebuah Gereja besar dari Jamaat Slavia. Kasus yang sama juga terjadi di Malaysia. Sebanyak 513 orang terkonfirmasi positif COVID-19 pasca sekelompok orang mengadakan pertemuan keagamaan. ${ }^{2}$ Penelitian Najib Burhani, Philips Vermonte, M. Bernie menemukan bahwa kelompok Jamaah Tabligh (JT) Indonesia, yang mengadakan Ijtima' di Malaysia pada 27 Februari - 1 Maret 2020 merupakan salah satu "super spreader", yang menularkan COVID-19 di daerah-daerah. ${ }^{3}$

Berbeda dengan temuan di atas, penelitian Mark Woodward, Syafiq Hashim, Amos Sukamto, Mills Heward, dan Nikolas Kuipers justru menunjukkan bahwa tokoh-tokoh agama telah memberikan kontribusi positif dan dapat mempengaruhi perilaku hidup sehat masyarakat dalam menanggulangi wabah COVID-19.4 Misalnya, fatwa Majelis Ulama Indonesia (MUI) tentang tatacara ibadah pada masa pandemi COVID-19 mendapat respons positif dan menjadi panduan mayoritas Muslim di Indonesia. ${ }^{5}$ Terlebih, ormas-ormas Islam seperti Nahdatul Ulama (NU), Muhammadiyah (MU), Front Pembela Islam (FPI) dan komunitas Jama'ah Tabligh (JT) memiliki pengikut dalam jumlah besar. Karena itu, para agamawan memiliki peran strategis dalam mengedukasi dan mempengaruhi perilaku Muslim di Indonesia. ${ }^{6}$

Kendati demikian, kebijakan pemerintah terkait penanggulangan COVID-19 tidak memberikan perhatian dan peran lebih kepada para tokoh agama. ${ }^{7}$ Sebab, kebijakan-kebijakan pemerintah selama ini terlalu memprioritaskan regulasi ekonomi, bantuan sosial, dan pengetatan protokol kesehatan. Bahkan, pada awal-awal pandemi COVID-19, 
respons Pemerintah Indonesia cenderung membingungkan dan tidak terarah. Hal itu terlihat dari kebijakan dan komunikasi antara Kementerian Kesehatan, Gugus Tugas COVID-19, Pemerintah Daerah dan Pusat yang saling tumpang tindih. ${ }^{8}$ Hal ini membuat peran tokoh agama dinilai bukan sebagai hal yang elementer untuk dapat melawan penyebaran COVID-19.

Menurut Mark Woodward, Najib Burhani, dan Syafiq Hashim, ormasormas Islam seperti NU dan Muhammadiyah berperan aktif membantu pemerintah dalam menanggulangi COVID-19. Melalui lembaga NU Care dan Lazis-MU, kedua ormas ini menolong masyarakat terdampak COVID-19. Muhammadiyah bahkan melakukan alihfungsi 77 rumah sakit sebagai Rumah Sakit Darurat COVID-19. Selain tokoh ormas, ulama-ulama kharismatik juga memiliki pengaruh signifikan untuk mengedukasi masyarakat tentang COVID-19, misalnya, Quraish Shihab dan Nasaruddin Umar.

Komunitas Muslim bisa saja menjadi penghalang dan super-spreader COVID-19 bila mereka tidak mendapat edukasi dan perspektif yang benar tentang COVID-19. Tokoh agama seperti Abdul Somad dan Najih Maemun Zubair awalnya merespons wabah COVID-19 secara sinis dan negatif. Para tokoh ini bahkan berpendapat bahwa COVID-19 adalah tentara Tuhan, konspirasi zionis dan hukuman bagi warga Tiongkok karena dianggap telah berbuat zalim terhadap komunitas Muslim Uyghur.

Berdasarkan hal tersebut, penelitian ini hendak mengkaji responsrespons komunitas Muslim baik dari kalangan ormas Islam seperti Majelis Ulama Indonesia (MUI), Nahdatul Ulama (NU), Muhammadiyah (MU), Front Pembela Islam (FPI), dan Jamaah Tabligh (JT) dan juga beberapa tokoh karismatik seperti Quraish Shihab, Nasaruddin Umar, dan Abdul Somad terhadap wabah COVID-19 yang terjadi di Indonesia. Pemilihan beberapa tokoh agama tersebut adalah selain faktor pengaruh yang diberikan juga disebabkan kebijakan-kebijakan para tokoh yang menimbulkan perbincangan dan kontroversi. 
Metode yang digunakan untuk melihat respons para pemuka Muslim dalam penelitian ini adalah metode survei literatur (literatur review). Data respons tersebut diperoleh dengan melakukan observasi terhadap situs-situs online berupa website resmi Majelis Ulama Indonesia (MUI), Muhammadiyah (MU), Nahdatul Ulama (NU), ataupun dari media youtube, koran online terkait respons pemuka agama. Data tersebut kemudian diinterpretasikan dengan menggunakan analisis wacana kritis yang dirumuskan oleh Norman Fairclough dengan Pendekatan Relasional Dialektikal (Relational-Dialectical Approach/DRA). Pendekatan DRA ini juga disebut dengan pendekatan perubahan sosial karena dalam teori ini muncul anggapan bahwa terdapat hubungan timbal balik saling mempengaruhi antara teks dan konteks wacana yang dimunculkan oleh para tokoh. ${ }^{9}$

Dengan metode ini, penelitian ini berusaha mengungkap munculnya respons (wacana kritis) dari para pemuka agama dan kaitannya dengan kebijakan Pemerintah Indonesia. Beberapa penelitian terdahulu seperti Ahmad Najib Burhani, Syafiq Hashim, Marcus Mietzner, Mark Woodward ${ }^{10}$ tidak melihat adanya pengaruh dan kaitan antara kebijakan pemerintah dan respons pemuka agama. Padahal, kebijakan pemerintah berupa edukasi dan peningkatan literasi tentang COVID-19 dapat mempengaruhi sikap dan perilaku pemuka agama. Dalam konteks ini, dengan menggunakan analisis wacana kritis Relational-Dialectical Approach/DRA oleh Norman Fairclugh, penelitian ini hendak mengisi ruang kosong (gap) tersebut dan melihat sisi di balik munculnya respons atau wacana kritis dari pemuka agama di Indonesia.

\section{B. Respons-Respons Komunitas Muslim terhadap COVID-19}

Komunitas Muslim Indonesia merespons wabah COVID-19 secara beragam. Mulai dari respons yang bersifat positif, hingga respons yang agak sinis, negatif dan bernada justifikatif. Respons komunitas Muslim Indonesia tidak dapat dilepaskan dari persoalan agama. Sekjen PP Muhammadiyah, Abdul Mu'ti mengkategorikan respons komunitas 
Muslim kepada dua kelompok, yaitu kelompok fundamentalis dan progresif.

Kalangan fundamentalis mengira bahwa pandemi COVID-19 adalah balasan dari Tuhan akibat perbuatan zalim manusia. Karena itu, kalangan fundamentalis menganjurkan agar menghadapi COVID-19 dengan memperbanyak aktivitas doa dan zikir. Sedangkan dalam pespektif kelompok progresif, wabah COVID-19 adalah konsekuensi atas pengrusakan yang dilakukan manusia terhadap alam. Karena itu, mereka menilai bahwa cara-cara medis, penerapan protokol kesehatan, dan sains adalah langkah yang tepat untuk memutus matarantai virus Corona.

Meskipun jumlah kelompok fundamentalis seperti Jama'ah Tabligh terbilang kecil, tapi aktivitas-aktivitas kelompok ini dapat membawa masalah dan memperluas penyebaran COVID-19 di Indonesia. Penelitian Philips Vermonte dan Najib Burhani menunjukkan bahwa kegiatan komunitas Jama'ah Tabligh yang mengadakan Ijtima' di Delhi dan Kuala Lumpur menjadi salah satu sumber penyebaran (super spreader) COVID-19 di Indonesia.

Berbeda dengan kalangan fundamentalis, kelompok progresif Muslim justru merespons COVID-19 secara lebih positif dan praktikal. Kelompok progresif seperti NU, Muhammadiyah, dan MUI mengeluarkan fatwafatwa berisi tuntunan ibadah selama masa Pendemi COVID-19. Bahkan, NU mendirikan NU-Care untuk menyalurkan bantuan warga terdampak COVID-19. Muhammadiyah mendirikan Muhammadiyah Covid Commad Center (MCCC). Bahkan, organisasi ini telah mengalokasikan dana sebesar 249 miliar, melibatkan 60.000 sukarelawan dan mengubah 77 rumah sakit di bawah lembaga Muhammadiyah dan Aisyah sebagai tempat perawatan pasien COVID-19. 


\section{Fatwa-Fatwa terkait COVID-19: MUI dan Ormas Islam Indonesia}

Pengeluaran fatwa-fatwa, kebijakan, dan tuntunan yang mengacu kepada protokol kesehatan adalah bentuk respons awal komunitas Muslim Indonesia terhadap wabah COVID-19. Majelis Ulama Indonesia (MUI) misalnya tercatat telah mengeluarkan tujuh fatwa seputar tatacara ibadah selama masa pandemi COVID-19. Tujuh fatwa yang dikeluarkan mulai dari 16 Maret sampai dengan 29 Juli 2020 mengatur mulai dari masalah kaifiat shalat bagi tenaga kesehatan yang memakai alat pelindung diri (APD), cara mengurus jenazah terinfeksi COVID-19, pemanfaatan zakat untuk penanggulangan COVID-19, tatacara sholat idul fitri, penyelenggaraan sholat berjamaah, hingga tatacara penyembelihan hewan korban saat wabah COVID-19.11

Fatwa yang dikeluarkan MUI tentang COVID-19 memiliki beberapa konteks. Pada awal-awal virus Corona merebak di Indonesia, MUI hanya mengeluarkan fatwa tentang tatacara ibadah yang bersifat umum. Hal itu sebagaimana tertuang dalam keputusan MUI dalam fatwa nomor 14 tahun 2020 tentang penyelenggaraan ibadah pada situasi terjadi wabah COVID-19. Dalam fatwa yang dikeluarkan pada 16 Maret 2020, MUI meminta orang-orang yang terpapar virus Corona agar segera melakukan isolasi diri. Fatwa ini sekaligus mengharuskan ibadah yang sifatnya berjamaah agar diganti dengan sholat secara sendiri, seperti mengganti sholat jumat dengan sholat zuhur. Dalam fatwa ini, MUI bahkan mengharamkan aktivitas ibadah-ibadah sunnat yang dilakukan secara berjamaah seperti sholat lima waktu dengan berjamaah, sholat tarawih dan idul fitri secara berjamaah. Pelarangan ini karena aktivitas tersebut dinilai memiliki risiko besar dan dapat menularkan virus COVID-19. ${ }^{12}$

Menurut Ketua Komisi Fatwa MUI, Hasanuddin AF, pemberlakuan fatwa MUI sesuai dengan zona masing-masing daerah. Ketika suatu kawasan beresiko tinggi terpapar COVID-19, maka aktivitas ibadah secara berjamaah menjadi terlarang dan dapat diganti dengan bentuk ibadah lainnya. Tapi, apabila risiko tertular COVID-19 terbilang rendah, 
maka aktivitas ibadah berjamaah boleh dilakukan dengan tetap menjaga protokol kesehatan. Demikian pula sebaliknya, apabila virus COVID-19 sudah tidak terkendali di suatu daerah, maka aktivitas ibadah berjamaah tidak boleh dilakukan, seperti mengikuti pengajian dan majelis taklim. ${ }^{13}$

Pada 26 Maret 2020, MUI kembali mengeluarkan fatwa tentang kaifiat sholat bagi tenaga kesehatan dengan memakai alat pelindung diri (APD). Fatwa ini keluar setelah muncul beberapa keluhan dari tenaga medis, yang merawat pasien COVID-19. Tenaga kesehatan menjadi kesulitan apabila harus melepas APD seperti baju hazmat ketika setiap kali hendak menunaikan sholat. Menjawab keluhan tersebut, MUI akhirnya memperbolehkan tenaga kesehatan melakukan ibadah sholat dengan menggunakan Alat Pelindung Diri (APD). Bahkan, jika tenaga kesehatan dalam kondisi hadas dan tidak mungkin bersuci (wudlu dan tayammum), mereka tetap diharuskan melaksanakan sholat dengan kondisi yang ada dan tidak harus mengulangi ibadah sholatnya. ${ }^{14}$

Sehari pasca fatwa kedua, MUI kembali mengeluarkan fatwa tentang pedoman pengurusan jenazah Muslim yang terinfeksi COVID-19. Fatwa ini keluar sebagai respons atas berbagai opini tentang tatacara yang ditempuh untuk menangani pasien terinfeksi COVID-19. Misalnya, Menteri Dalam Negeri (Mendagri), Tito Karnavian sempat melontarkan teori bahwa jenazah tertular COVID-19 sebaiknya dikremasi. Cara ini dianggap efektif untuk menghilangkan jejak virus Corona dibandingkan dengan cara dikubur. ${ }^{15}$ Dalam fatwa ini, MUI akhirnya memutuskan bahwa jenazah seorang Muslim yang terpapar virus Corona harus tetap memperoleh haknya yaitu dimandikan, dikafani, disholati, dan dikuburkan dengan tetap mematuhi protokol kesehatan dan berdasarkan ketentuan syariat Islam.

Selain fatwa tentang tatacara ibadah, Majelis Ulama Indonesia (MUI) juga mengeluarkan fatwa tentang pemanfaatan harta zakat, infaq, dan sadaqah untuk penanggulangan wabah COVID-19. Perdebatan seputar pemanfaatan harta zakat ini muncul karena zakat biasanya diberikan 
kepada delapan asnaf (golongan) seperti fakir, miskin hingga ibnu sabil. Pemanfaatan zakat kepada warga terdampak wabah (COVID-19) belum ada kejelasan dan masih menjadi kontroversi. Merespons hal tersebut, MUI akhirnya memutuskan bahwa pemberian zakat terhadap warga terdampak COVID-19, sebagaimana tertuang dalam fatwa nomor 23 tahun 2020 tentang hukum pemanfaatan harta zakat, infaq dan sadaqah adalah boleh. ${ }^{16}$

Semasa COVID-19, MUI juga mengeluarkan fatwa-fatwa yang mencegah orang-orang berkerumun. Dalam fatwa nomor 28 tahun 2020, MUI menghindarkan sholat idul fitri secara berjamaah di mesjid atau di lapangan. Untuk mencegah hal ini, MUI mengeluarkan kaifiat sholat idul fitri dalam suasana COVID-19. Selain sholat Idul Fitri, MUI juga mengeluarkan panduan sholat jumat dan sholat berjamaah. Dalam fatwa nomor 31 tahun 2020, Komisi Fatwa MUI menganjurkan bagi orangorang yang berada di zona aman (kuning dan hijau) agar sholat dengan menerapkan physical distancing yaitu dengan menjaga jarak antar saf. Fatwa terakhir yang dikeluarkan MUI adalah berkaitan dengan tata cara Sholat Idul adha dan penyembelihan hewan kurban. Dalam fatwa nomor 36 tahun 2020, MUI memutuskan agar sholat idul fitri dan pelaksanaan pemotongan hewan kurban dilaksakan dengan menerapkan protokol kesehatan. ${ }^{17}$

Fatwa yang dikeluarkan oleh Majelis Ulama Indonesia (MUI) ini sejalan dengan Lembaga Fatwa Dunia di berbagai negara, seperti Arab Saudi, Yordania, Mesir, dan beberapa negara Muslim lainnya. Dar alIfta' Yordania misalnya memfatwakan gugurnya kewajiban sholat jumat, dengan alasan khawatir tertular COVID-19, hingga hukum swab di bulan Ramadhan tidak membatalkan puasa. Ulama Arab Saudi juga ikut merespons pandemi COVID-19. Grand Mufti Arab Saudi Syeikh Abdul Aziz Ali Syeikh menganjurkan agar shalat tarawih pada bulan Ramadhan dilakukan di rumah karena adanya uzur akibat pandemi. Pemerintah Arab Saudi bahkan membatasi pelaksanaan ibadah haji (hajj al-mahdud) untuk mencegah penularan virus corona. Di Mesir, Mufti Mesir Syauqi 
Allam memfatwakan bahwa melakukan vaksinasi (akh al-laqah) adalah wajib syar'i (wajibun syar'iyyun). Walaupun kemudian diketahui dalam materi vaksin terkandung unsur babi, tapi Dar al-Ifta' Mesir tetap memfatwakan kebolehan penggunaan vaksin tersebut, karena unsur babi telah berubah tabi'atnya menjadi materi lain yang berbeda dan baru. ${ }^{18}$

Merespons fatwa Majelis Ulama Indonesia (MUI) dan Lembaga Fatwa Dunia tersebut, ormas-ormas Islam di Indonesia seperti Muhammadiyah dan Nahdatul Ulama (NU) kemudian mengeluarkan fatwa seputar COVID-19. Pada 31 Maret 2020, Muhammadiyah mengeluarkan Surat Edaran Pimpinan Pusat Muhammadiyah No. 03/EDR/I.0/E/ 2020 tentang Tuntunan Ibadah dalam Kondisi Darurat COVID-19. Sebelumnya, Muhammadiyah juga mengeluarkan Surat Maklumat Pimpinan Pusat Muhammadiyah Nomor 02/MLM/I.0/H/2020 tentang Wabah Coronavirus Disease (Covid-19) dan Nomor 03/I.0/B/2020 tentang Penyelenggaraan Salat Jumat dan Fardu Berjamaah Saat Terjadi Wabah Coronavirus Disease (Covid-19). ${ }^{19}$

Dalam fatwa-fatwa tersebut, Muhammadiyah menegaskan bahwa sholat malam seperti ibadah sholat tarawih sebaiknya dilaksanakan di rumah dan tidak di mesjid. Anjuran ini karena Muhammadiyah mempertimbangkan bahwa sholat tarawih berjamaah di mesjid dapat menimbulkan keramaian dan menjadi media penularan COVID-19. Untuk menghindarkan bahaya COVID-19, Muhammadiyah memfatwakan bahwa umat Islam tidak perlu melakukan sholat Idul Fitri secara berjamaah pada masa pandemi. Bahkan, Muhammadiyah melarang umat Islam untuk melakukan mudik. ${ }^{20}$ Senada dengan Muhammadiyah, respons Nahdatul Ulama (NU) terhadap COVID-19 juga dengan mengeluarkan fatwa dan himbauan keagamaan seputar panduan ibadah pada masa pandemi. NU pertamakali meminta kepada para pengikut untuk tetap tenang dan merespons penyebaran virus Corona secara proporsional. NU meminta ibadah-ibadah ritual secara berjamaah seperti sholat Jumat, ibadah di mesjid selama masa pandemi sebaiknya harus dihindari. Orang-orang yang terkonfirmasi positif virus 
Corona mesti dilarang mengikuti pertemuan-pertemuan ibadah. Kendati demikian, NU mengalami banyak hambatan dari para pengikut saat menghimbau umat Islam untuk menghindari sholat tarawih dan sholat idul fitri pada masa pandemi COVID-19. ${ }^{21}$

Komunitas pesantren-pesantren di Indonesia ikut menjadi perhatian Nahdatul Ulama (NU) selama masa pandemi COVID-19. NU melalui Rabithah Ma'hid Islamiyah (RMI) NU mengeluarkan panduan dan kebijakan untuk pencegahan virus Corona di pesantren-pesantren. Kebijakan tersebut tertuan dalam Surat Edaran Nomor 835/A/PPRMI/ SE/III/2020 pada 13 Maret 2020 M/18 Rajab $1441 \mathrm{H}$ tentang Protokol Pencegahan Penyebaran Coronavirus Disease (Covid-19) pada Pondok Pesantren. RMI-NU memberikan panduan pencegahan Corona sesuai dengan protokol kesehatan seperti memeriksa suhu tubuh saat memasuki pesantren, mencuci tangan pakai sabun, menyediakan ruang isolasi, dan beberapa langkah yang sesuai dengan petunjuk Gugus Tugas COVID-19. ${ }^{22}$

\section{Klaster Baru COVID-19: Tinjauan Aktivitas FPI dan Jamaah Tabligh}

Himbauan pemerintah dan fatwa Majelis Ulama Indonesia (MUI) pada masa pandemi COVID-19 tidak sepenuhnya dipatuhi oleh ormas Islam dan kelompok keagamaan di Indonesia. Front Pembela Islam (FPI) dan Jama'ah Tabligh (JT) masih melakukan aktivitas ibadah secara berkerumun dan mengundang banyak orang. Saat wabah COVID-19 merebak di Wuhan China, Jamaah Tabligh Indonesia masih aktif mengikuti ijtima (pertemuan) di Delhi (India) dan Kuala Lumpur (Malaysia). Ijtima' serupa juga sempat akan digelar di Gowa, Sulawesi Selatan, tapi pertemuan itu akhirnya dibatalkan setelah muncul berbagai desakan dari sejumlah pihak. ${ }^{23}$

Selain Jamaah Tabligh, respons negatif juga diberikan oleh Front Pembela Islam (FPI). Saat kepulangan Habib Rizieq Shihab (HRS) di Bandara Soekarno-Hatta, ribuan pengikut HRS menyambut 
kedatangannya di bandara tanpa memperhatikan protokol kesehatan. Antusiasme pendukung HRS ini akhirnya menyebabkan kemacetan di sepanjang jalan tol menuju Bandara Soekorna-Hatta. Bahkan, kerumunan ini juga mengakibatkan sejumlah penerbangan dari dan menuju Soekarno-Hatta mengalami penundaan dan terpaksa dibatalkan. Padahal, HRS dalam laman Youtube "Markaz FPI" telah mengingatkan kepada seluruh anggota dan pengikut FPI agar mematuhi protokol kesehatan yang ditetapkan tim Gugus Tugas COVID-19 dan Pemerintah Indonesia. $^{24}$

Kerumunan massa Front Pembela Islam (FPI) di Bandara SoekarnoHatta berlanjut hingga ke tempat-tempat lain. Di Petamburan, DKI Jakarta, Habieb Rizieq Shihab menggelar acara pernikahan putrinya dengan mengundang banyak orang. Meskipun panitia acara mengaku telah berupaya menjalankan protokol kesehatan, tapi massa yang tak terkendali akhirnya menyebabkan kerumunan banyak orang. Setelah di Petamburan, Habieb Rizieq Shihab kembali menggelar acara Maulid Nabi di Megamendung Bogor. Aktivitas-aktivitas inilah yang kemudian mengakibatkan ormas FPI diadukan ke pihak kepolisian dan dipidana karena dianggap melanggar regulasi protokol kesehatan pada masa pandemi COVID-19. ${ }^{25}$

Pasca acara FPI di Petamburan dan Megamendung, tim Gugus Tugas COVID-19 melakukan deteksi COVID-19 melalui rapid test dan swab test. Berdasarkan data Kementerian Kesehatan, 80 orang yang menghadiri acara Habib Rizieq di Petamburan dan Tebet terkonfirmasi positif COVID-19. ${ }^{26}$ Bahkan, Kapolda Metro Jaya Irjen Polisi Fadil Imran melaporkan bahwa kerumunan Habib Rizieq memunculkan empat klaster baru COVID-19. Empat klaster tersebut adalah klaster akad nikah di Petamburan, klaster Tebet, klaster Bandara Soekarno-Hatta, dan klaster Megamendung, Bogor, Jawa Barat. ${ }^{27}$

Klaster baru COVID-19 juga muncul dari kegiatan ijtima' yang digelar Jama'ah Tabligh. Bahkan, tiga kegiatan ijtima' di Kuala Lumpur 
(Malaysia) pada 27 Februari - 1 Maret, Delhi (India) pada 13-15 Maret, dan 18 Maret yang dibatalkan di Gowa (Indonesia) ditenggarai sebagai media utama penyebar virus COVID-19. Orang-orang yang hadir dalam acara ijtima' tersebut diduga telah menularkan virus COVID-19. Bahkan, Institute for Policy Analysis of Conflict (IPAC) melaporkan bahwa 1.068 dari 14.265 kasus yang terjadi di Indonesia sampai 11 Mei 2020 adalah berasal dari klaster Gowa. ${ }^{28}$ Menurut Najib Burhani, Jamaah Tabligh cenderung bersikap acuh terhadap kondisi pandemi COVID-19. Hal itu terkuak dari akun sosial media pengikut Jamaah Tabligh. Dalam laman medsos tersebut, status yang ditulis adalah “Tuhan adalah lebih kuasa dari virus Corona. Kami takut terhadap Tuhan, bukan virus". Pada awalawal pandemi menyerang Indonesia, Jamaah Tabligh bahkan masih melakukan kegiatan ijtima' dengan tanpa memperhatikan protokol kesehatan. Mareka masih berjabat tangan, berpelukan tanpa alat pelindung diri. ${ }^{29}$

\section{Respons Logis dan Praktikal Ormas Islam terhadap COVID-19}

Selain mengeluarkan tuntunan seputar COVID-19, dua ormas Islam terbesar di Indonesia seperti Nahdatul Ulama (NU) dan Muhammadiyyah (MU) juga merespons dampak COVID-19 secara praktis dan logis. Kedua ormas Islam ini telah menyalurkan bantuan sosial berupa sembako, uang, dan mengalihfungsikan pusat kesehatan menjadi rumah sakit darurat COVID-19. Respons praktis seperti ini memberikan dampak besar dalam membantu warga-warga yang terdampak COVID-19, baik secara finansial maupun medis. Misalnya, alihfungsi rumah sakit yang dilakukan oleh Muhammadiyah dapat secara efektif membantu warga tertular COVID-19.

Respons Muhammadiyah terhadap COVID-19 dapat diklasifikasikan kepada dua kategori. Pertama, Muhammadiyyah memberikan respons secara teologis dengan mengeluarkan fatwa dan menganjrukan umat agar menggelar doa supaya dijauhkan dari bahaya COVID-19. Kedua, sebagai lembaga masyarakat, Muhammadiyyah mengerahkan segenap sumber 
daya dan aset yang mereka miliki untuk melawan bahaya pandemi COVID-19. Dua klasifikasi tersebut membuat respons Muhammadiyah agak berbeda dari respons komunitas Muslim lain seperti FPI dan Jamaah Tabligh. Muhammadiyah tidak hanya mengeluarkan fatwafatwa dan himbauan keagamaan, tapi ormas Islam ini juga membangun spirit umat dengan menekankan prinsip "Jihad Kemanusiaan". "Jihad Kemanusiaan" adalah konsep yang dibangun Muhammadiyah agar umat tidak hanya berpangku tangan dan mengandalkan pemerintah untuk melawan virus Corona. Tapi, “Jihad Kemanusiaan” menekankan bahwa berjuang melawan COVID-19 adalah kewajiban bagi setiap Muslim yang mampu. ${ }^{30}$

Konsep "Jihad Kemanusiaan" yang dicetuskan Muhammadiyah berdasarkan kepada prinsip maqāsid al-sharī'ah. Konsep maqāsid al-sharī'ah itu sendiri menekankan bahwa ajaran Islam harus sesuai dengan tujuantujuan syariat yaitu menjaga agama, jiwa, akal, keturunan, dan harta benda. Dalam konteks itu, "Jihad Kemanusiaan” juga merupakan bagian tak terpisahkan dari lima tujuan syariat tersebut. Sebagai pendukung dalil "Jihad Kemanusiaan", Muhammadiyah mengutip QS [5]: 32 untuk mempertegas bahwa berjuang dalam hal kemanusiaan adalah dianjurkan dalam ajaran Islam. Untuk merealisasikan "Jihad Kemanusiaan", Muhammadiyah mengerahkan berbagai macam upaya untuk melawan COVID-19, baik energi, uang, dan sumber daya manusia. Panitia bahkan membatalkan kegiatan kongres tahunan yang sudah dijadwalkan di Surakarta pada Juni 2020 demi mencegah penularan COVID-19. ${ }^{31}$

Salah satu bentuk realisasi "Jihad Kemanusiaan" ormas Muhammadiyah adalah memperkuat dan menambah aspek layanan sosial untuk mencegah COVID-19. Muhammadiyah mengkonversi 77 rumah sakit di bawah naungan Muhammadiyah dan Aisiyah menjadi rumah sakit darurat COVID-19. Rumah sakit ini lalu dimanfaatkan untuk merawat pasien COVID-19 yang tidak tertampung di rumah sakit pemerintah. Sebagian besar rumah sakit darurat ini dibangun di Pulau Jawa. Hingga saat ini, rumah sakit darurat COVID-19 telah 
menangani sekira 4.000 pasien tertular virus Corona. ${ }^{32}$ Pada 5 Maret 2020, Muhammadiyah meresmikan Muhammadiyah COVID-19 Command Center (MCCC) untuk mengkordinir segala aktivitas Muhammadiyah yang berkaitan dengan penanganan COVID-19. Sampai Desember 2020, MCCC telah memiliki 30 cabang di seluruh Indonesia. Berdasarkan data MCCC, Muhammadiyah telah menghabiskan lebih dari 249 miliar rupiah dan telah mengerahkan 60.000 sukarelawan untuk membantu penanganan wabah COVID-19 di seluruh Indonesia. Melalui lembaga ini, Muhammadiyah mampu secara mandiri memproduksi Alat Pelindung Diri (APD) seperti baju hazmat, sarung tangan, dan masker. Bahkan, Muhammadiyah melakukan penyemprotan disenfektan di rumahrumah ibadah baik mesjid, gereja, candi, dan gedung publik lainnya. ${ }^{33}$

Di bawah MCCC, Muhammadiyah juga mengelar konsultasi psikologis secara gratis bagi pasein traumatis akibat dampak COVID-19. Selain konsultasi, Muhammadiyah juga memberikan bantuan finansial serta bahan pokok bagi pasien COVID-19 yang membutuhkan. Bantuan financial yang disalurkan oleh lembaga Muhammadiyah dilaksanakan oleh sebuah badan khusus yang disebut Lembaga Amil Zakat Infaq Sadaqah Muhammadiyah (LAZIS-MU). ${ }^{34}$ Meskipun ikut membantu pemerintah selama pandemi COVID-19, Muhammadiyah juga bersikap kritis terhadap pemerintah dengan mengkiritik kebijakan-kebijakan yang dikeluarkan pemerintah dalam menangani COVID-19. Saat Presiden Joko Widodo mengumumkan hendak membuka aktivitas ekonomi, Muhammadiyah ikut mengkritik. Bagi Muhammadiyah, pembukaan aktivitas ekonomi masyarakat tanpa menyiapkan infrasturuktur dapat meningkatkan jumlah kasus penularan COVID-19.35

Di samping Muhammadiyah, Nahdatul Ulama (NU) merupakan organisasi Islam terbasar di Indonesia dan memiliki banyak pengikut dari berbagai kalangan. Menurut klaim NU, jumlah pengikut hingga 2015 mencapai 50 juta orang. Bahkan, sejumlah pesantren di Indonesia memiliki afiliasi dengan ormas NU. Data Rabithah Ma'hid Islamiyah (RMI) mencatat sekira 24.000 pesantren di seluruh Indonesia berafiliasi 
dengan NU, mulai dari Jawa Timur, Jawa Tengah, Jawa Barat, hingga ke Pulau Sumatera. ${ }^{36}$ Berdasarkan data tersebut, maka Nahdatul Ulama (NU) memiliki pengaruh dan kontrol kuat dalam mempengaruhi perilaku dan sikap masyarakat Islam Indonesia. ${ }^{37}$

NU menggelar kegiatan doa dan shalawat sejak wabah pendemi COVID-19 masuk ke Indonesia pada awal Maret 2020. Pengurus Besar Nahdatul Ulama (PBNU) sempat menggelar doa bersama dan pembacaan sholawat tibb al-qulūb di Masjid Annahdiah Gedung PBNU, Jakarta Pusat. ${ }^{38}$ Gus Baha, salah satu kyai karismatik NU juga menganjurkan, selain melakukan ikhtiar bersifat medis dengan mengikuti protokol kesehatan, umat Islam juga diminta memperbanyak istighfar karena COVID-19 adalah bersumber dari Allah SWT. ${ }^{39}$

Nahdatul Ulama (NU) melalui RMI meminta kepada Pemerintah Indonesia untuk turun tangan dan terlibat lebih dalam mencegah dan menanggulangi COVID-19 di pesantren-pesantren di seluruh Indonesia. Berdasarkan pengamatan RMI, informasi pemerintah tentang kasus COVID-19 di pesantren-pasantren di Indonesia masih belum akurat. Pada 11 Agustus 2020, setidaknya sudah terdapat 21 kasus dan enam di antaranya diketahui telah menjadi klustur pesantren. Karena itu, RMI meminta agar pemerintah lebih ketat mengeluarkan izin pembukaan pesantren pada masa pendemi COVID-19. ${ }^{40}$

\section{COVID-19 dan Pandangan Kontroversial}

Sejak Maret 2019, COVID-19 telah menyerang Wuhan, China dan menular ke berbagai negara seperti Asia di antaranya Singapura, Filipina, dan Indonesia. Tapi, sejumlah pemimpin agama masih merespons kejadian ini secara skeptis, negatif, dan bahkan tidak mempercayai adanya virus Corona di Indonesia. Mereka berdalih bahwa virus Corona adalah tentara Allah yang diutus Tuhan untuk menghukum orang-orang yang zalim terhadap umat Islam. Corona bahkan dianggap sebagai konspirasi Zionis dan Barat untuk memperlemah kekuatan umat Islam. 
Salah satu ulama yang memberikan komentar terkait wabah COVID-19 adalah Ustadz Abdul Somad (UAS). Ia menafsirkan Virus Corona yang tengah menjangkiti warga Wuhan, China sebagai "tentara Allah". Komentar UAS inipun secara cepat tersebar dalam media sosial baik Youtube, Facebook, dan juga Twitter. Ceramah yang dibagikan oleh Channel Haji News, telah ditonton lebih dari 38 ribu kali dan telah mendapat 278 like, 385 dislike, dan beberapa komentar negatif dari para netizen per tanggal 26 Desember 2020. Komentar UAS tersebut kemudian direspons secara beragam. Beberapa netizen setuju dengan pendapat UAS, tapi sebagian ikut mengkritisi pemahaman UAS yang menyebut bahwa "Corona adalah tentara Allah". ${ }^{41}$

Ceramah UAS di medsos inipun bahkan ikut direspons oleh sejumlah ulama dan tokoh Muslim seperti Quraish Shihab, Azyumardi Azra, Ulil Absar Abdallah, Muqsith Ghazali dan beberapa tokoh Nahdatul Ulama (NU) dan Muhammadiyah (MU). Quraish Shihab tidak setuju bahwa COVID-19 disebut tentara Allah. Menurutnya, Corona lebih tepat disebut sebagai bencana yang merupakan ujian bagi umat manusia, agar mereka tidak berperilaku angkuh dan mengakui kelemahannya di hadapan Tuhan. Pendapat yang sama juga dikemukakan oleh Azyumardi Azra. Tulisannya di Republika Online berjudul "COVID-19: Splinter Agama", Azra menolak pendapat bahwa Corona adalah azab bagi warga Wuhan, China karena data statistik menunjukkan bahwa sebagian penduduk Wuhan adalah Muslim dan beberapa warga Wuhan yang beragama Islam ikut meninggal akibat pandemi COVID-19. ${ }^{42}$

Ceramah yang menimbulkan kontroversi tersebut disampaikan UAS di hadapan ribuan jamaah di Malaysia pada awal Pendemi COVID-19. Ia mengatakan bahwa Virus Corona di Wuhan China adalah salah satu bentuk tentara Allah yang dikirim untuk membantu umat Islam. Umat Islam selama ini dinilai masih lemah, kehilangan kesultanan, khalifah dan hanya bisa berzikir serta membaca al-Qur'an. Kondisi inilah yang menyebabkan Allah SWT akhirnya menolong umat Islam, sehingga orang-orang Muslim di Uyghur tidak terkena COVID-19. Menurut UAS, 
salah satu penyebab Muslim Uyghur tidak terpapar Virus Corona karena mereka menjalankan ajaran Islam seperti menjaga kesucian, memakan binatang setelah disembelih dan dimasak. ${ }^{43}$

Isi ceramah UAS di hadapan para jamaah di Malaysia tampaknya merupakan respons atas berbagai isu yang merebak di media cetak dan media sosial seputar asal dan penyebab Virus Corona. Beberapa media nasional dan internasional memberitakan bahwa Muslim Uyghur mengalami penindasan oleh Pemerintah China. Berdasarkan laporan penyelidikan Komite PBB pada 18 Agustus 2018, sekira satu juta Muslim Uyghur dan kelompok Muslim lainnya telah ditahan di wilayah Xianjiang Barat dan menjalani program reedukasi (pendidikan ulang). Bahkan, Humans Right Watch, sebagaimana dilansir BBC Indonesia melaporkan bahwa Suku Uyghur diawasi secara ketat dan mereka dipaksa belajar bahasa Mandarin dan diancam agar meninggalkan keyakinan agama. ${ }^{44}$ Kendati demikian, berita ini juga dibantah oleh Pemerintah China sendiri dan juga pemuka agama Muslim di Uyghur. ${ }^{45}$

Selain UAS, komentar kontroversial terkait COVID-19 juga diberikan oleh seorang tokoh NU, Kyai Najih Maemun Zubair. Kyai Najih adalah tokoh ulama karismatik di kalangan NU dan Pesantren Anwar, Sarang, Jawa Tengah. Ia adalah anak Kyai Maemun Zubaer yang merupakan seorang ulama dan tokoh pembesar dari Partai Persatuan Pembangunan (PPP). Kyai Najih memiliki pengaruh yang kuat di kalangan umat Islam terutama di komunitas NU Garis Lurus dan mantan pengikut Hizbut Tahrir Indonesia (HTI). ${ }^{46}$

Awal-awal virus Corona menyebar di Indonesia, Kyai Najih mengkritisi fatwa Majelis Ulama Indonesia (MUI) dan Nahdatul Ulama (NU) yang melarang umat Islam menggelar sholat jumat di mesjid-mesjid. Kritik tersebut berdasarkan pandangan Kyai Najih dari perspektif hukum Islam. Di samping argumen figh, Kyai Najih juga menduga bahwa COVID-19 adalah virus yang sengaja diciptakan oleh Zionis Israel, yang bertujuan untuk mengurangi jumlah populasi Muslim sampai 500 juta 
orang. Bahkan, Kyai Najih menuduh bahwa ormas-ormas Islam yang melarang acara-acara keagamaan seperti doa dan shalat berjamaah di mesjid adalah bagian dari kelompok Zionis. ${ }^{47}$

Menurut Kyai Najih, COVID-19 belum dapat dikategorikan sebagai pandemi. Menurutnya, suatu peristiwa disebut pandemi apabila telah memakan korban lebih dari 100.000 orang. Sedangkan di Indonesia, jumlah korban meninggal masih jauh dari angka tersebut. Dengan demikian, dispensasi (rukhsoh) dalam urusan agama belum dapat diberlakukan di Indonesia. Berdasarkan hal itu, Kyai Najih berpandangan bahwa COVID-19 adalah suatu bentuk penjajahan yang telah dipersiapkan oleh WHO, Amerika Serikat, China dan musuh-musuh Islam. ${ }^{48}$

\section{COVID-19, Kebijakan Pemerintah, dan Respons Pemuka Agama}

Data di atas menunjukkan bahwa respons komunitas Muslim Indonesia terbagi kepada dua kategori. Kategori pertama adalah kelompok yang cenderung menanggapi wabah COVID-19 secara negatif, dengan menganggap COVID-19 sebagai konspirasi Barat dan Zionis, tentara Tuhan, dan hukuman dari Allah SWT bagi orang-orang kafir. Pada sisi lain, terdapat beberapa ormas dan pemuka agama yang merespons penyebaran COVID-19 secara lebih positif dan praktikal, dengan menggalang dana, menyalurkan bantuan kepada korban terdampak COVID-19, dan mengeluarkan fatwa untuk mematuhi protokol kesehatan, sebagaimana dilakukan oleh MUI, NU, dan Muhammadiyah.

Dengan menggunakan analisis wacana kritis pendekatan RelationalDialectical Approach/DRA oleh Norman Fairclugh, maka diskursus yang muncul dari para tokoh keagamaan, tidak dapat hanya dilihat dari perspektif teks semata, tapi memiliki kaitan dengan konteks perubahan sosial masyarakat Muslim pada masa pandemi COVID-19. Sebab antara diskursus wacana dengan konteks sosial masyarakat Muslim dapat saling mempengaruhi. Pada satu sisi, respons negatif misalnya muncul karena dipengaruhi kondisi sosial masyarakat, tapi pada sisi lain, diskursus 
yang dimunculkan para agamawan juga bertujuan untuk mengkonstruk dan membentuk perubahan sosial masyarakat Muslim. ${ }^{49}$

Respons negatif para pemuka agama muncul karena lemahnya rezim Jokowi dalam mengantisipasi penyebaran wabah COVID-19, sebagaimana disebut juga oleh beberapa analis seperti Mietzner, Woodward, Burhani, dan Hashim..$^{50}$ Kelemahan itu tampak dari ketidaksiapan pemerintah dalam menghadirkan berbagai peralatan dan infrastruktur medis. Terlebih lagi, respons pemerintah yang lamban dan kebijakan rezim yang membingungkan membuat tingkat penyebaran COVID-19 semakin meluas. Padahal, sejak awal pandemi COVID-19 terjadi Wuhan, China, WHO telah memperingatkan agar Indonesia mempersiapkan segala sesuatu untuk menghadapi virus ini. Tapi, peringatan itu luput dari perhatian pemerintah. Menteri Kesehatan, Terawan Agus Putranto misalnya menyangkal bahaya serius COVID-19. Terawan bahkan menyebut virus ini tidak akan mampu berkembang di iklim tropis seperti Indonesia. Bahkan, Menteri Terawan menyamakan COVID-19 dengan virus influenza biasa lainnya, sehingga tidak perlu menggunakan alat pelindung diri (APD). ${ }^{51}$

Respons negatif dari para pemuka agama seperti Ustadz Abdul Somad, Kyai Najih, dan Habib Luthfi juga muncul akibat pemerintah tidak mengakomodir, memberikan edukasi dan tidak mampu meyakinkan para pemuka agama tentang bahaya COVID-19. Sebab, pemerintah selama ini terlalu fokus kepada persiapan pencegahan COVID-19 secara fisik, penyeimbangan laju ekonomi, sehingga abai mengakomodir para pemuka agama. Hal inilah yang dalam pendekatan Relational-Dialectical Approach/ DRA disebut oleh Norman Fairclugh sebagai penyebab munculnya wacana kritis para pemuka agama, sebagaimana dilontarkan oleh Kyai Najih dan Ustadz Abdul Somad. ${ }^{52}$

Data di atas menunjukkan bahwa ketidakmampuan pemerintah untuk mengakomodir dan meyakinkan para pemuka Muslim (ulama) dan komunitas beragama mengenai COVID-19 dapat menyebabkan 
munculnya respons negatif di kalangan pemuka agama Islam di Indonesia, sebagaimana direpresentasikan oleh Ustadz Abdul Somad, Gus Najih Maimun Zubair, dan Habib Luthfi. Begitu juga dengan kelompok Jama'ah Tabligh (JT), sehingga edukasi seputar COVID-19 perlu dilakukan secara lebih intensif. Hal ini mengingat banyaknya jumlah pengikut dan besarnya pengaruh yang dimiliki oleh para pemuka agama tersebut. Terlebih, tradisi keagamaan mereka selama ini lebih banyak berkerumun. Apabila hal ini dibiarkan dan tidak segera ditindaklanjuti akan dapat meperparah penyebaran kasus COVID-19 di Indonesia dan bahkan kembali menjadi "super-spreader" di Indonesia.

Berdasarkan persoalan di atas, maka Pemerintah Indonesia perlu melakukan pendekatan kepada para pemuka agama secara lebih intensif. Sebab, para individu dan kelompok ini belum mendapat edukasi tentang COVID-19 secara maksimal dan dari segi haluan politik, mereka ini memiliki sikap, ideologi, dan pilihan politik yang berbeda dengan Presiden Indonesia terpilih saat ini. Faktor ini, yang dalam penelitian Mietzner, langsung ataupun tidak langsung dinilai dapat mempengaruhi kepercayaan mereka terhadap pemerintah. ${ }^{53}$ Oleh karena itu, pendekatan emosional dan komunikasi yang intensif sangat perlu dilakukan kepada para tokoh Muslim ini. Sebab, kepercayaan dan tindakan masyarakat pengikutnya besar dipengaruhi oleh pemikiran para tokoh yang mereka panuti. $^{54}$

Selain itu, tidak dapat dipungkiri bahwa peran pemuka agama (Muslim) dalam menghadapi wabah COVID-19, sebagaimana disebut Mahfud MD, Azra dan Abdul Mu'ti, memiliki peran yang sangat signifikan. Karena itu, Pemerintah Indonesia khususnya melalui Kementerian Kesehatan, Kementerian Agama dan pihak-pihak terkait perlu memperbaiki pola komunikasi dengan para tokoh agama, terutama tokoh Muslim yang telah memberikan pernyataan kontroversial terkait COVID-19. Pola komunikasi itu termasuk memberikan aturan yang jelas, khususnya tentang regulasi aktivitas ibadah yang melibatkan orang dalam jumlah banyak, seperti regulasi penyembelihan hewan qurban, 
harus ada aturan jelas yang dikeluarkan pemerintah. ${ }^{55}$

Melalui pendekatan dialog dan persuasif secara baik, maka pemuka agama yang awalnya kontra dengan kebijakan pemerintah dapat dirangkul dan bahkan digandeng untuk ikut mengkampanyekan bahaya COVID-19. Pelibatan pemuka agama dalam kampanye melawan wabah COVID-19, dalam beberapa penelitian, memiliki peran signifikan untuk memutus rantai penyebaran COVID-19. Hal ini tidak terlepas dari sosok tokoh agama yang memang dapat berfungsi sebagai aktor sosial yang bisa mempengaruhi perilaku dan pikiran masyarakat masyarakat. ${ }^{56}$

\section{Kesimpulan}

Penelitian ini menghasilkan beberapa temuan penting terkait respons komunitas Islam Indonesia dalam penanganan Covid-19 di Indonesia. Tanggapan beberapa komunitas Muslim terhadap Covid-19 belum sepenuhnya sesuai dengan pedoman pemerintah Indonesia. Selama pandemi Covid-19, beberapa pemimpin agama ikut menggelar dan mempromosikan kegiatan ibadah secara berkerumun. Hal ini terlihat dari reaksi yang menunjukkan pro dan kontra dari masyarakat Muslim dan sikap penolakan terhadap kebijakan yang ditetapkan pemerintah. Dalam konteks ini, organisasi Islam arus utama seperti NU, MU dan MUI telah mengambil pendekatan yang logis dan realistis dengan meminta para pengikutnya untuk mematuhi protokol kesehatan sesuai instruksi pemerintah. Pada sisi lai, beberapa tokoh Muslim seperti Kyai Najih, Ustadz Abdul Somad, dan Habib Luthfi merespons wabah pandemi COVID-19 dengan memunculkan narasi yang cenderung negatif. Mereka menganggap COVID-19 sebagai konspirasi Barat dan Zionis Israel, tentara Tuhan ataupun hukuman bagi masyarakat yang berbuat zalim terhadap umat Islam.

Selain itu, dengan menggunakan pendekatan Relational-Dialectical Approach/ DRA oleh Norman Fairclugh tampak bahwa reaksi negatif para pemuka agama dilatari oleh beberapa konteks. Pemerintah dinilai 
lamban mengantisipasi penyebaran wabah COVID-19, yang tampak dari ketidaksiapan menghadirkan peralatan dan infrastruktur medis, kebijakan yang membingungkan, dan pernyataan ambigu dari pejabat pemerintah. Selain faktor tersebut, respons negatif oleh bebarapa pemuka agama juga dilatarbelakangi oleh sikap pemerintah yang tidak mengakomodir, memberikan edukasi dan tidak mampu meyakinkan para pemuka agama tentang bahaya COVID-19. Faktor inilah yang kemudian memicu munculnya diskursus negatif oleh para tokoh Muslim di Indonesia dalam menghadapi COVID-19. Untuk menghadapi persoalan ini, Pemerintah Indonesia, melalui sektor-sektor terkait, harus melakukan pendekatan secara persuasif, perbaikan pola komunikasi, dan menggandeng ormas dan tokoh agama agar bersama melawan penyebaran COVID-19. 


\section{DAFTAR PUSTAKA}

Abdul Rohman Ahdori. “Respons Virus Corona, PBNU Doa Bersama Dan Bacakan Shalawat," 2020. https://www.nu.or.id/post/read/117405/ respons-virus-corona--pbnu-doa-bersama-dan-bacakan-shalawat.

Abdul Somad. "Allah Kirim Tentara Corona Untuk Melindungi Muslim Uyghur," Haji News, Diposting 11 Februari 2020, YouTube Video, 9:19., n.d. https://youtu.be/6mHsVx8goTs.

Amos Sukamto. "Religious Community Responses to the Public Policy of the Indonesian Government Related to the COVID-19 Pandemic." Journal of Law, Religion and State 8, no. 1 (2020): 273-83.

Andrian Pratama Taher. “'Ijtima Jamaah Tabligh Di Gowa Dibatalkan, Jokowi Ucap Terima Kasih', 2020. Https://Tirto.Id/Ijtima-JamaahTabligh-Di-Gowa-Dibatalkan-Jokowi-Ucap-Terima-Kasih-EGbc (Diakses Pada 27 Januari 2021).," n.d.

Arif Jamali Muis. “Jihad Kemanusiaan Muhammadiyah,” 2020. https:// covid19.muhammadiyah.id/jihad-kemanusiaan-muhammadiyah/.

Arrobi, Mohammad Zaki, and Amsa Nadzifah. "Otoritas Agama di Era Korona: Dari Fragmentasi Ke Konvergensi?" MAARIF 15, no. 1 (June 30, 2020): 197-215. https://doi.org/10.47651/mrf.v15i1.85.

Azyumardi Azra. “Covid-19: Splinter Agama," 2020. https://republika. co.id/berita/ q7s4i4282/virus-corona-splinter-agama-1.

BBC News. “Massa Demo Kedubes Cina, Tuntut Hentikan Persekusi Muslim Uighur," 2018. https://www.bbc.com/indonesia/ indonesia-46643055.

“Biografi KH. Muhammad Najih Maimoen,” 2020. https://www.laduni. $\mathrm{id} /$ post/read /67816/biografi-kh-muhammad-najih-maimoen.

Burhani, Ahmad Najib. “Comparing Tablighi Jamaat and Muhammadiyah 
Responses To," no. 2020 (2020): 10.

CNN Indonesia. "Tito Soal Bakar Jenazah Covid-19: Itu Kata Teori, Bukan Saya"," 2020. https://www.cnnindonesia.com/ nasional/20200724173042-20-528675/tito-soal-bakar-jenazah-covid19-itu-kata-teori-bukan-saya.

Fauziah Mursid. "RMI NU Respons Banyak Kasus Penularan Covid-19 Di Pesantren," n.d. https://republika.co.id/berita/qewd16396/rminu-respons-banyak-kasus-penularan-covid19-di-pesantren.

Fitraya Ramadhanny. "Benarkah Muslim Ditindas Di Xinjiang China?," 2018. https://news.detik.com/berita/d-4027365/benarkah-muslimditindas-di-xinjiang-china.

Gisela Swaragita. “Dr. Corona vs. Coronavirus: Muhammadiyah Special Center Fighting COVID-19 in Indonesia," 2020. https://www. thejakartapost.com/news/2020/03/11/dr-corona-vs-coronavirusmuhammadiyah-special-center-fighting-covid-19-in-indonesia. html.

Hanafi, Yusuf, Ahmad Taufiq, Muhamad Saefi, M. Alifudin Ikhsan, Tsania Nur Diyana, Andy Hadiyanto, Yedi Purwanto, and Ahmad Imam Mawardi. “Indonesian Ulema Council Fatwa On Religious Practices During Covid-19 Pandemic: An Investigation Of Muslim Compliance." Preprint. In Review, June 9, 2020. https://doi. org/10.21203/rs.3.rs-33784/v1.

Hasyim, Syafiq. "Singapore I 5 May 2020 Covid-19, Islamic Civil Society and State Capacity in Indonesia," no. 2020 (2020): 8.

HUMAS Kemenko Polhukam. “Dialog Dengan Tokoh Agama Soal Penanganan Covid, Menko Polhukam: Peran Ulama Sangat Penting." Polkam.Go.Id. Accessed March 12, 2021. https://polkam. go.id/dialog-tokoh-agama-soal-penanganan-covid-menkopolhukam/.

Husni Sahal. “Respons Covid-19, Gus Baha: Selain Ikhtiar Medis, Kita 
Harus Memperbanyak Istighfar," 2020. https://www.nu.or.id/post/ $\mathrm{read} / 118124 /$ respons-covid-19--gus-baha--selain-ikhtiar-medis-kita-harus-memperbanyak-istighfar.

Imam Rahman Cahyadi. "Total Ada 77 Orang Positif Covid-19 Dari Kegiatan Di Petamburan, Tebet Dan Mega Mendung," 2020. https://www.pikiran-rakyat.com/nasional/pr-011000946/bukancuma-satu-ada-empat-klaster-covid-19-dari-kerumunan-habibrizieq? page $=2$.

Institute for Policy Analysis of Conflict. "Religious 'Super-Spreaders' in Indonesia: Managing the Risk of Stigmatisation." Institute for Policy Analysis of Conflict, 2020, 3-10.

“Jumlah Pesantren Tradisional Masih Dominan." Accessed January 9, 2020. https://www.nu.or.id/post/read/42981/jumlah-pesantrentradisional-masih-dominan.

Lane, Max. “The Politics of National and Local Responses to the COVID-19 Pandemic in Indonesia," no. 2020 (2020): 9.

Majelis Ulama Indonesia (MUI). “Fatwa MUI," 2020. https://mui.or.id/ fatwa/.

Mark Woodward. “Nahdatul Ulama, Pesantren, and the Pandemic," 2020. https://www.insideindonesia.org/nahdlatul-ulama-pesantrenand-the-pandemic.

Mietzner, Marcus. "Populist Anti-Scientism, Religious Polarisation, and Institutionalised Corruption: How Indonesia's Democratic Decline Shaped Its COVID-19 Response." Journal of Current Southeast Asian Affairs 39, no. 2 (August 2020): 227-49. https://doi. org/10.1177/1868103420935561.

Mohammad Bernie. "Mengurai Penyebab Masifnya Penyebaran COVID-19 Klaster Ijtima Gowa," January 12, 2021. https://tirto. $\mathrm{id} /$ mengurai-penyebab-masifnya-penyebaran-covid-19-klasterijtima-gowa-e2bh. 
MUI. “Fatwa No 14 Tahun 2020 - Penyelenggaraan Ibadah Dalam Situasi Terjadi Wabah Covid-19," 2020. https://mui.or.id/berita/27674/ fatwa-penyelenggaraan-ibadah-dalam-situasi-terja di-wabahcovid-19/.

- - - " "Fatwa No 17 Tahun 2020 - Pedoman Kaifiat Shalat Bagi Tenaga Kesehatan Yang Memakai Alat Pelindung Diri (APD) Saat Merawat Dan Menangani Pasien COVID-19," 2020. https://mui.or.id/produk/ fatwa/27748/fatwa-no-17-tahun-2020-pedoman-kaifiat-shalat-bagitenaga-kesehatan-yang-memakai-alat-pelindung-diri-apd-saatmerawat-dan-menangani-pasien-covid-19/.

- - - . "Fatwa No 23 Tahun 2020 - Pemanfaatan Harta Zakat, Infak, Dan Shadaqah Untuk Penanggulangan Wabah COVID-19 Dan Dampaknya," 2020. https://mui.or.id/produk/fatwa/27990/ pemanfaatan-harta-zakat-infak-dan-shadaqah-untukpenanggulangan-wabah-covid-19-dan-dampaknya/.

- - - "Fatwa No 36 MUI Tentang Shalat Idul Adha Dan Penyembelihan Hewan Kurban Saat Wabah COVID-19," 2020. https://mui.or.id/ produk/ fatwa/28586/fatwa-no-36-mui-tentang-shalat-idul-adhadan-penyembelihan-hewan-kurban-saat-wabah-covid-19/.

- - - "Peran MUI Dan Lembaga Fatwa Dunia Dalam Penanggulangan COVID-19," 2021. https://mui.or.id/opini/31115/peran-mui-danlembaga-fatwa-dunia-dalam-penanggulangan-covid-19/.

Najih Maemun Zubaer. Gus Najih Maimoen Menentang Keputusan MUI Pusat Melarang Orang Jumatan Di Masjid Karena Corona. YouTube Video, 2020. https://www.youtube.com/watch?v=pUX08oZdzzA.

Najwa Shihab, Shihab Quraish. Benarkah Corona Tentara Allah? YouTube Video, 2020. https://www.youtube.com/watch?v=gtd4xR YjY4.

Nicholas Kuipers. "Encouraging Indonesians to Pray from Home During the COVID-19 Pandemic." Journal of Experimental Political Science, 2020, 1-12. 
Norman Fairclough. Language and Power. New York: Addison Wesley Longman, 1989.

Rahvy, Aisyah, and Ilham Akhsanu Ridlo. "A Timeline Response: How Does Islamic Organizations Respond to COVID-19 in Indonesia?" Preprint. SocArXiv, June 6, 2020. https://doi.org/10.31235/osf.io/ kzhy9.

Rian Firmansyah. "Kemenkes: 80 Orang Yang Menghadiri Kegiatan Habib Rizieq Di Petamburan Dan Tebet Positif Corona," 2020. https://prfmnews.pikiran-rakyat.com/nasional/pr-13998378/ kemenkes-80-orang-yang-menghadiri-kegiatan-habib-rizieq-dipetamburan-dan-tebet-positif-corona.

Roland Hughes. "Muslim Uighur Dan Perlakuan Cina Terhadap Mereka, Yang Perlu Anda Ketahui," 2018. https://www.bbc.com/indonesia/ dunia-46601638.

Sri Wahyuni. "Government's Statements on New Normal Confusing: Muhammadiyah," 2020. https:/www.thejakartapost.com/ news/2020/05/29/governments-statements-on-new-normalconfusing-muhammadiyah.html.

Suara Muhammadiyah. "Maklumat PP Muhammadiyah Tentang Wabah Covid-19," 2020.https://www.suaramuhammadiyah.id/2020/03/15/ maklumat-pp-muhammadiyah-tentang-wabah-covid-19/.

The Jakarta Post. "Crowds Cause Major Jams in Marking Rizieq Shihab's Homecoming," 2020. https://www.thejakartapost.com/ news/2020/11/10/crowds-cause-major-jams-in-marking-rizieqshihabs-homecoming.html.

"Total Ada 77 Orang Positif COVID-19 Dari Kegiatan Di Petamburan, Tebet, Dan Megamendung." Accessed January 7, 2020. https:// www.beritasatu.com/kesehatan/700783/total-ada-77-orang-positifcovid19-dari-kegiatan-di-petamburan-tebet-dan-mega-mendung.

Vermonte, Philips. “Karakteristik dan Persebaran COVID-19 di Indonesia: 
Temuan Awal," n.d., 12.

Vissia Ita Yulianto, Hakimul Ikhwan. "How Religions and Religious Leaders Can Help to Combat the COVID-19 Pandemic: Indonesia's Experience," 2020. https://theconversation.com/how-religionsand-religious-leaders-can-help-to-combat-the-covid-19-pandemicindonesias-experience-140342.

VOI. "Reasons For Determining Rizieq Shihab Suspect In Case Of Violation Of The Megamendung Health Center," 2020. https:// voi.id/en/berita/24175/alasan-penetapan-tersangka-rizieq-shihabdalam-perkara-pelanggaran-prokes-megamendung.

Yendell, Alexander, Oliver Hidalgo, and Carolin Hillenbrand. “The Role of Religious Actors in the COVID-19 Pandemic: A Theory-Based Empirical Analysis with Policy Recommendations for Action," 2021. https://doi.org/10.17901/AKBP1.10.2021.

Zalik Nuryana, Suyadi, and Niki Alma FF. “The Fiqh of Disaster: The Mitigation of COVID-19 in the Perspective of Islamic EducationNeuroscience." International Journal of Disaster Risk Reduction 1, no. 51 (2020): 4-5. 


\section{Endnotes}

1. Institute for Policy Analysis of Conflict, "Religious 'Super-Spreaders' in Indonesia: Managing the Risk of Stigmatisation," Institute for Policy Analysis of Conflict, 2020, 3-10.

2. Hakimul Ikhwan Vissia Ita Yulianto, "How Religions and Religious Leaders Can Help to Combat the COVID-19 Pandemic: Indonesia's Experience," 2020, https://theconversation.com/how-religions-and-religious-leaderscan-help-to-combat-the-covid-19-pandemic-indonesias-experience-140342 (diakses 5 Januari 2020).

3. Ahmad Najib Burhani, "Comparing Tablighi Jamaat and Muhammadiyah Responses To COVID-19," no. 2020 (2020): 10; Philips Vermonte dan Teguh Yudo Wijaksono, "Karakteristik dan Persebaran COVID-19 di Indonesia: Temuan Awal," CSIS Commentaries (2020): 1-12; Mohammad Bernie, "Mengurai Penyebab Masifnya Penyebaran COVID-19 Klaster Ijtima Gowa," 2020. https://tirto.id/ mengurai-penyebab-masifnya-penyebaran-covid-19klaster-ijtima-gowa-e2bh (diakses 12 januari 2021).

4. Vissia Ita Yulianto dan Hakimul Ikhwan, "How Religions and Religious Leaders Can Help to Combat the COVID-19 Pandemic: Indonesia's Experience"; Syafiq Hasyim, "Covid-19, Islamic Civil Society and State Capacity in Indonesia," ISEAS Perspective (2020): 1-8; Amos Sukamto, "Religious Community Responses to the Public Policy of the Indonesian Government Related to the COVID-19 Pandemic," Journal of Law, Religion and State 8, no. 1 (2020): 273-83; Nicholas Kuipers, "Encouraging Indonesians to Pray from Home During the COVID-19 Pandemic," Journal of Experimental Political Science, 2020, 1-12.

5. Yusuf Hanafi et al., "Indonesian Ulema Council Fatwa On Religious Practices During Covid-19 Pandemic: An Investigation Of Muslim Compliance," preprint (In Review, June 9, 2020), https://doi.org/10.21203/rs.3.rs-33784/ v1; Mohammad Zaki Arrobi and Amsa Nadzifah, “Otoritas Agama di Era Korona: Dari Fragmentasi Ke Konvergensi?," MAARIF 15, no. 1 (June 30, 2020): 197-215, https://doi.org/10.47651/mrf.v15i1.85. 
6. Institute for Policy Analysis of Conflict, "Religious 'Super-Spreaders' in Indonesia: Managing the Risk of Stigmatisation," 1-4; Burhani, "Comparing Tablighi Jamaat and Muhammadiyah Responses To COVID-19", 1-10; Mark Woodward, "Nahdatul Ulama, Pesantren, and the Pandemic," 2020, https:// www.insideindonesia.org/nahdlatul-ulama-pesantren-and-the-pandemic (diakses 11 Januari 2020).

7. Hasyim, "Covid-19, Islamic Civil Society and State Capacity in Indonesia," 1-8.

8. Marcus Mietzner, "Populist Anti-Scientism, Religious Polarisation, and Institutionalised Corruption: How Indonesia's Democratic Decline Shaped Its COVID-19 Response," Journal of Current Southeast Asian Affairs 39, no. 2 (August 2020): 227-49, https://doi.org/10.1177/1868103420935561; Max Lane, "The Politics of National and Local Responses to the COVID-19 Pandemic in Indonesia," ISEAS Perspective (2020): 1-9.

9. Norman Fairclough, Language and Power (New York: Addison Wesley Longman, 1989).

10. Burhani, "Comparing Tablighi Jamaat and Muhammadiyah Responses to COVID-19"; Hasyim, "Singapore I 5 May 2020 Covid-19, Islamic Civil Society and State Capacity in Indonesia"; Mietzner, "Populist Anti-Scientism, Religious Polarisation, and Institutionalised Corruption"; Mark Woodward, "Nahdatul Ulama, Pesantren, and the Pandemic."

11. Majelis Ulama Indonesia (MUI), “Fatwa MUI,” 2020, https://mui.or.id/ fatwa/.

12. MUI, "Fatwa No 14 Tahun 2020 - Penyelenggaraan Ibadah Dalam Situasi Terjadi Wabah Covid-19," 2020, https://mui.or.id/berita/27674/fatwapenyelenggaraan-ibadah-dalam-situasi-terja di-wabah-covid-19/.

13. [CSL STYLE ERROR: reference with no printed form.].

14. MUI, “Fatwa No 17 Tahun 2020 - Pedoman Kaifiat Shalat Bagi Tenaga Kesehatan Yang Memakai Alat Pelindung Diri (APD) Saat Merawat Dan Menangani Pasien COVID-19," 2020, https://mui.or.id/produk/fatwa/27748/ fatwa-no-17-tahun-2020-pedoman-kaifiat-shalat-bagi-tenaga-kesehatanyang-memakai-alat-pelindung-diri-apd-saat-merawat-dan-menanganipasien-covid-19/ (diakses pada 27 Januari 2021). 
15. “Tito Soal Bakar Jenazah Covid-19: Itu Kata Teori, Bukan Saya"," 2020, https://www.cnnindonesia.com/nasional/20200724173042-20-528675/titosoal-bakar-jenazah-covid-19-itu-kata-teori-bukan-saya (diakses pada 27 Januari 2021).

16. MUI, “Fatwa No 23 Tahun 2020 - Pemanfaatan Harta Zakat, Infak, Dan Shadaqah Untuk Penanggulangan Wabah COVID-19 Dan Dampaknya," 2020, https://mui.or.id/produk/fatwa /27990/pemanfaatan-harta-zakatinfak-dan-shadaqah-untuk-penanggulangan-wabah-covid-19-dandampaknya/ (diakses pada 27 Januari 2021).

17. MUI, "Fatwa No 36 MUI Tentang Shalat Idul Adha Dan Penyembelihan Hewan Kurban Saat Wabah COVID-19," 2020, https://mui.or.id/ produk/ fatwa/28586/fatwa-no-36-mui-tentang-shalat-idul-adha-danpenyembelihan-hewan-kurban-saat-wabah-covid-19/ (diakses pada 27 Januari 2021).

18. MUI, "Peran MUI Dan Lembaga Fatwa Dunia Dalam Penanggulangan COVID-19," 2021, https://mui.or.id/opini/31115/peran-mui-dan-lembagafatwa-dunia-dalam-penanggulangan-covid-19/ (diakses pada 27 Januari 2021).

19. Suara Muhammadiyah, "Maklumat PP Muhammadiyah Tentang Wabah Covid-19," 2020, https://www.suaramuhammadiyah.id/2020/03/15/ maklumat-pp-muhammadiyah-tentang-wabah-covid-19/ (diakses pada 27 Januari 2021).

20. Suara Muhammadiyah, "Maklumat PP Muhammadiyah Tentang Wabah Covid-19," 2020, https://www.suaramuhammadiyah.id/2020/03/15/ maklumat-pp-muhammadiyah-tentang-wabah-covid-19/ (diakses pada 27 Januari 2021).

21. Hasyim, "Covid-19, Islamic Civil Society and State Capacity in Indonesia," 3.

22. Suara Muhammadiyah, "Maklumat PP Muhammadiyah Tentang Wabah Covid-19."

23. Andrian Pratama Taher, “'Ijtima Jamaah Tabligh Di Gowa Dibatalkan, Jokowi Ucap Terima Kasih', 2020. Https://Tirto.Id/Ijtima-Jamaah-TablighDi-Gowa-Dibatalkan-Jokowi-Ucap-Terima-Kasih-EGbc (Diakses Pada 27 
Januari 2021).," n.d.

24. The Jakarta Post, "Crowds Cause Major Jams in Marking Rizieq Shihab's Homecoming," 2020, https://www.thejakartapost.com/news/2020/11/10/ crowds-cause-major-jams-in-marking-rizieq-shihabs-homecoming.html. (diaksespada27Januari2021).1,27]]\}," issued":\{“date-parts":[[“2020"]]\}\}\}],"sc hema":"https://github.com/citation-style-language/schema/raw/master/cslcitation.json"\}

25. VOI, "Reasons For Determining Rizieq Shihab Suspect In Case Of Violation Of The Megamendung Health Center," 2020, https://voi.id/en/berita/24175/ alasan-penetapan-tersangka-rizieq-shihab-dalam-perkara-pelanggaranprokes-megamendung(Diaksespada27Januari2021).1,27]]\},"issued":\{“dateparts":[["2020"]]\}\}\}],"schema":"https://github.com/citation-style-language/ schema/raw/master/csl-citation.json"'

26. Rian Firmansyah, "Kemenkes: 80 Orang Yang Menghadiri Kegiatan Habib Rizieq di Petamburan dan Tebet Positif Corona," 2020, https://prfmnews. pikiran-rakyat.com/nasional/pr-13998378/kemenkes-80-orang-yangmenghadiri-kegiatan-habib-rizieq-di-petamburan-dan-tebet-positif-corona; "Total Ada 77 Orang Positif COVID-19 dari Kegiatan di Petamburan, Tebet, dan Megamendung," accessed January 7, 2020, https://www. beritasatu.com/kesehatan/700783/total-ada-77-orang-positif-covid19-darikegiatan-di-petamburan-tebet-dan-mega-mendung.2020, https://www. beritasatu.com/kesehatan/700783/total-ada-77-orang-positif-covid19-darikegiatan-di-petamburan-tebet-dan-mega-mendung."," plainCitation":"Rian Firmansyah, "Kemenkes: 80 Orang Yang Menghadiri Kegiatan Habib Rizieq Di Petamburan Dan Tebet Positif Corona," 2020, https://prfmnews. pikiran-rakyat.com/nasional/pr-13998378/kemenkes-80-orang-yangmenghadiri-kegiatan-habib-rizieq-di-petamburan-dan-tebet-positif-corona; "Total Ada 77 Orang Positif COVID-19 Dari Kegiatan Di Petamburan, Tebet, Dan Megamendung," accessed January 7, 2020, https://www. beritasatu.com/kesehatan/700783/total-ada-77-orang-positif-covid19dari-kegiatan-di-petamburan-tebet-dan-mega-mendung.", "'dontUpdate" :true," noteIndex":26\}," citationItems":[\{“id":75," uris":[“http://zotero.org/ users/local/2I5N9WG0/items/GI6I48SJ"],"uri":[“http://zotero.org/users/ local/2I5N9WG0/items/GI6I48SJ"],"itemData":\{“id":75,"type":"article- 
newspaper", "title":"Kemenkes: 80 Orang yang Menghadiri Kegiatan Habib Rizieq di Petamburan dan Tebet Positif Corona", "URL":"https://prfmnews. pikiran-rakyat.com/nasional/pr-13998378/kemenkes-80-orang-yangmenghadiri-kegiatan-habib-rizieq-di-petamburan-dan-tebet-positif-coron a", "'author":[[“family":"',,"given":"Rian Firmansyah"\}]," accessed":\{“dateparts":[[“2021",1,7]]\},"issued":\{“date-parts":[[“2020"]]\}\}\},\{“id":76,"uris":[“ http://zotero.org/users/local/2I5N9WG0/items/3SVGU6UG"],"uri":[“http:// zotero.org/users/local/2I5N9WG0/items/3SVGU6UG"],"itemData":\{“id":76, "type":"article-newspaper","title":"TotalAda77OrangPositifCOVID-19dari Kegiatan di Petamburan, Tebet, dan Megamendung","URL":"'https://www. beritasatu.com/kesehatan/700783/total-ada-77-orang-positif-covid19-darikegiatan-di-petamburan-tebet-dan-mega-mendung", "'accessed":\{"date-par ts":[[“2020",1,7]]\}\}\}],"schema":"https://github.com/citation-style-language/ schema/raw/master/csl-citation.json"'

27. Imam Rahman Cahyadi, “Total Ada 77 Orang Positif Covid-19 Dari Kegiatan Di Petamburan, Tebet Dan Mega Mendung," 2020, https://www.pikiranrakyat.com/nasional/pr-011000946/bukan-cuma-satu-ada-empat-klastercovid-19-dari-kerumunan-habib-rizieq?page=2 (diakses pada 07 Januari 2021). 1,7]]\},"issued":\{“date-parts":[[“2020"]]\}\}\}],"schema"::"https://github. com/citation-style-language/schema/raw/master/csl-citation.json"'\}

28. Institute for Policy Analysis of Conflict, "Religious Religious 'SuperSpreaders' in Indonesia: Managing the Risk of Stigmatisation," 3-10.

29. Burhani, "Comparing Tablighi Jamaat and Muhammadiyah Responses to COVID-19," 4.

30. Arif Jamali Muis, “Jihad Kemanusiaan Muhammadiyah,” 2020, https:// covid19 .muhammadiyah.id/jihad-kemanusiaan-muhammadiyah/ diakses pada 27 Januaro 2021.

31. Burhani, "Comparing Tablighi Jamaat and Muhammadiyah Responses to COVID-19," 1-2.

32. Suyadi, Zalik Nuryana, dan Niki Alma FF, "The Fiqh of Disaster: The Mitigation of COVID-19 in the Perspective of Islamic EducationNeuroscience," International Journal of Disaster Risk Reduction 1, no. 51 (2020): 4-5. 
33. Gisela Swaragita, “Dr. Corona vs. Coronavirus: Muhammadiyah Special Center Fighting COVID-19 in Indonesia," 2020, https://www.thejakartapost. com/news/2020/03/11/dr-corona-vs-coronavirus-muhammadiyah-specialcenter-fighting-covid-19-in-indonesia.html.

34. Hasyim, "Covid-19, Islamic Civil Society and State Capacity in Indonesia", 3.

35. Sri Wahyuni, "Government's Statements on New Normal Confusing: Muhammadiyah," 2020, https://www.thejakartapost.com/news/2020/05/29/ governments-statements-on-new-normal-confusing-muhammadiyah.html. (Diakses pada 27 Januari 2021).

36. “Jumlah Pesantren Tradisional Masih Dominan," accessed January 9, 2020, https://www.nu.or.id/post/read/42981/jumlah-pesantren-tradisional-masihdominan.

37. "Jumlah Pesantren Tradisional Masih Dominan."

38. Abdul Rohman Ahdori, "Respons Virus Corona, PBNU Doa Bersama Dan Bacakan Shalawat," 2020, https://www.nu.or.id/post/read/117405/responsvirus-corona--pbnu-doa-bersama-dan-bacakan-shalawat (Diakses pada 26 Desember 2020).

39. Husni Sahal, "Respons Covid-19, Gus Baha: Selain Ikhtiar Medis, Kita Harus Memperbanyak Istighfar," 2020, https://www.nu.or.id/post/ read/118124/respons-covid-19--gus-baha--selain-ikhtiar-medis--kita-harusmemperbanyak-istighfar (Diakses pada 26 Desember 2020).

40. Fauziah Mursid, "RMI NU Respons Banyak Kasus Penularan Covid-19 Di Pesantren," n.d., https://republika.co.id/berita/qewd16396/rmi-nu-responsbanyak-kasus-penularan-covid19-di-pesantren diakses pada 26 Desember 2020.

41. Somad, Abdul, "Allah Kirim Tentara Corona Untuk Melindungi Muslim Uyghur," Haji News, Diposting 11 Februari 2020, YouTube Video, 9:19., n.d., https://youtu.be/6mHsVx8goTs.

42. Shihab Quraish dan Najwa Shihab, "Benarkah Corona Tentara Allah?", Najwa Shihab, diposting pada 23 Maret 2020, Youtube Video, 4:50. https:// www.youtube.com/watch?v=gtd4xR YjY4; Azyumardi Azra, "Covid-19: 
Splinter Agama," 2020, https://republika.co.id/berita/ q7s4i4282/viruscorona-splinter-agama-1.

43. Somad, Abdul, "Allah Kirim Tentara Corona Untuk Melindungi Muslim Uyghur," Haji News, Diposting 11 Februari 2020, YouTube Video, 9:19., n.d., https://youtu.be/6mHsVx8goTs.

44. Roland Hughes, "Muslim Uighur dan Perlakuan Cina Terhadap Mereka, yang Perlu Anda Ketahui," 2018, https://www.bbc.com/indonesia/ dunia-46601638 (diakses pada 26 Desember 2020) ; BBC News, "Massa Demo Kedubes Cina, Tuntut Hentikan Persekusi Muslim Uighur," 2018, https:// www.bbc.com/indonesia/indonesia-46643055 (diakses pada 26 Desember 2020).

45. Fitraya Ramadhanny, "Benarkah Muslim Ditindas Di Xinjiang China?," 2018, https://news.detik.com/berita/d-4027365/benarkah-muslim-ditindasdi-xinjiang-china (Diakses pada 26 Desember 2020).

46. “Biografi KH. Muhammad Najih Maimoen," 2020, https://www.laduni.id/ post/read /67816/biografi-kh-muhammad-najih-maimoen (diakses pada 27 Januari 2021).

47. Najih Maemun Zubaer, "Gus Najih Maimoen Menentang Keputusan MUI Pusat Melarang Orang Jumatan di Masjid Karena Corona", YouTube Video, 2020, https://www.youtube.com/watch?v=pUX08oZdzzA.

48. Najih Maemun Zubaer, “Gus Najih Maimoen Menentang Keputusan MUI Pusat Melarang Orang Jumatan di Masjid Karena Corona", YouTube Video, 2020, https://www.youtube.com/watch?v=pUX08oZdzzA.

49. Fairclugh, Language and Power, 70-72.

50. "Crowds Cause Major Jams in Marking Rizieq Shihab's Homecoming"; "Nahdatul Ulama, Pesantren, and the Pandemic"; Burhani, "Comparing Tablighi Jamaat and Muhammadiyah Responses To"; Hasyim, "Singapore I 5 May 2020 Covid-19, Islamic Civil Society and State Capacity in Indo nesia."”"plainCitation":"'“Crowds Cause Major Jams in Marking Rizieq Shihab's Homecoming"; "Nahdatul Ulama, Pesantren, and the Pandemic"; Burhani, "Comparing Tablighi Jamaat and Muhammadiyah Responses To"; Hasyim, "Singapore I 5 May 2020 Covid-19, Islamic Civil Society and State Capacity in Indonesia."”, "'noteIndex":50\},"citationItems":[\{“id":73,"uris"::[" 
http://zotero.org/users/local/2I5N9WG0/items/WUNJZY3L"],"uri":[“http:// zotero.org/users/local/2I5N9WG0/items/WUNJZY3L"],"itemData":\{“id":73 ,"type":"article-newspaper","title":"Crowds cause major jams in marking Rizieq Shihab's homecoming","URL":"https://www.thejakartapost. com/news/2020/11/10/crowds-cause-major-jams-in-marking-rizieqshihabs-homecoming.html","author":[\{“family":"',,"given":"The Jakarta Post"\}]," accessed":\{“date-parts":[[“2021",1,27]]\},"issued":\{“date-parts":[[" 2020"]]\}\}\},\{“id":62,"uris":[“http://zotero.org/users/local/2I5N9WG0/items/ ZJYICD5K"],"uri”:[“"http://zotero.org/users/local/2I5N9WG0/items/ZJYIC D5K"],"itemData":\{“id":62,"type":"article-newspaper","title":"Nahdatul Ulama, Pesantren, and the Pandemic", "URL":"https://www.insideindonesia. org/nahdlatul-ulama-pesantren-and-the-pandemic", "author":[\{“family" :"',", given"::"Mark Woodward"\}]," accessed":\{“date-parts":[[“2020”,1,11 ]]\},"issued":\{“date-parts":[[“2020"]]\}\}\},\{“id":5,"uris":[“http://zotero.org/ users/local/2I5N9WG0/items/PWJYHI3Z"],"uri”:[“http://zotero.org/users/ local/2I5N9WG0/items/PWJYHI3Z"],"itemData":\{“id":5,"type":"article-jo urnal", "issue":"2020", "language":"en", "page":"10","source":"Zotero"," ti tle":"Comparing Tablighi Jamaat and Muhammadiyah Responses to", "au thor":[\{“family":"Burhani", "given":"Ahmad Najib"\}],"issued":\{“date-pa rts":[[“2020”]]\}\}\},\{“id":4,"uris":[“http://zotero.org/users/local/2I5N9WG0/ items/8PBEX324”],"uri”:[“http://zotero.org/users/local/2I5N9WG0/items/8P BEX324"],"itemData":\{“id":4,"type":" article-journal", "issue":"2020", "lang uage":"en", "page":" 8", "source":"Zotero", "title":"Singapore | 5 May 2020 Covid-19, Islamic Civil Society and State Capacity in Indonesia", "author":[ \{“family":"Hasyim","given":"Syafiq"\}],"issued":\{“date-parts":[[“2020”]]\}\}\}] ,"schema":"https://github.com/citation-style-language/schema/raw/master/ csl-citation.json"\}

51. Hasyim, "Singapore I 5 May 2020 Covid-19, Islamic Civil Society and State Capacity in Indonesia"; Aisyah Rahvy and Ilham Akhsanu Ridlo, "A Timeline Response: How Does Islamic Organizations Respond to COVID-19 in Indonesia?," preprint (SocArXiv, June 6, 2020), https://doi.org/10.31235/ osf.io/kzhy9.

52. Language and Power, 70-82.

53. Marcus Mietzner, "Populist Anti-Scientism, Religious Polarisation, and 
Institutionalised Corruption: How Indonesia's Democratic Decline Shaped Its COVID-19 Response," Journal of Current Southeast Asian Affairs 39, no. 2 (August 2020): 227-49, https://doi.org/10.1177/1868103420935561.

54. "Religious Community Responses to the Public Policy of the Indonesian Government Related to the COVID-19 Pandemic."

55. HUMAS Kemenko Polhukam, "Dialog Dengan Tokoh Agama Soal Penanganan Covid, Menko Polhukam: Peran Ulama Sangat Penting," Polkam.Go.Id, diakses 12 Maret, 2021, https://polkam.go.id/dialog-tokohagama-soal-penanganan-covid-menko-polhukam/.

56. Alexander Yendell, Oliver Hidalgo, and Carolin Hillenbrand, "The Role of Religious Actors in the COVID-19 Pandemic: A Theory-Based Empirical Analysis with Policy Recommendations for Action," 2021, https://doi. org/10.17901/AKBP1.10.2021. 